\title{
Early In Vitro Fertilization Improves Development of Bovine Ova Heat Stressed During In Vitro Maturation
}

\author{
G. E. Schrock, A. M. Saxton, F. N. Schrick, and J. L. Edwards ${ }^{1}$ \\ Department of Animal Science, Tennessee Agricultural Experiment Station, The University of Tennessee Institute of Agriculture, \\ Knoxville 37996-4574
}

\begin{abstract}
The objectives were to examine the development of embryos derived from control $\left(38.5^{\circ} \mathrm{C}\right)$ or heat-stressed ova $\left[41.0^{\circ} \mathrm{C}\right.$ during the first $12 \mathrm{~h}$ of in vitro maturation (hIVM)] when in vitro fertilization (IVF) was performed at $16,18,20,24$, or 30 hIVM. Effects of heat stress in compromising ovum development depended on when IVF was performed (in vitro maturation temperature $\times$ IVF time interaction). When IVF was performed at 24 or 30 hIVM, fewer heat-stressed ova developed to the blastocyst stage compared with the respective controls. In contrast, when IVF was performed at 16, 18, or 20 hIVM, more heat-stressed ova developed to the blastocyst stage compared with the respective controls. Performing IVF earlier than usual was beneficial, because the ability of heat-stressed ova to develop to the blastocyst stage was improved when IVF was performed at 18 or 20 vs. 24 hIVM. Blastocyst stage and quality were equivalent to non-heat-stressed controls regardless of IVF time. Control ova undergoing IVF at $20,24,30$, or $32 \mathrm{hIVM}$ and heat-stressed ova undergoing IVF at $16,18,20$, or $24 \mathrm{hIVM}$ were compared for blastocyst development by multisource regression. Although linear and quadratic slopes were similar, heat stress reduced the peak and shifted the developmental response of ova by $7.3 \mathrm{~h}$. In other words, obtaining optimal blastocyst development from heat-stressed ova would depend on performing IVF at 19.5 hIVM compared with 26.7 hIVM for non-heat-stressed controls. Heat-induced reductions in peak blastocyst development significantly reduced the window of time available to perform IVF and obtain $\geq 20 \%$ blastocyst development. In summary, results support an effect of heat stress to hasten developmentally important events during oocyte maturation. The inability of earlier IVF to fully restore the development of heat-stressed ova to that of non-heat-stressed controls highlights the importance of further study.
\end{abstract}

Received January 2, 2007.

Accepted April 26, 2007.

${ }^{1}$ Corresponding author: jedwards@utk.edu
Key words: heat stress, oocyte, maturation, fertilization

\section{INTRODUCTION}

Heat-induced reductions in the fertility of lactating dairy cows may be due in large part to direct effects of elevated maternal temperatures that compromise the ovum as it matures in preparation for fertilization. In particular, elevated ambient temperatures sufficient to raise rectal temperatures $\geq 41.0^{\circ} \mathrm{C}$ during estrus were previously shown to increase the proportion of degenerate or retarded embryos recovered after insemination of superovulated Holstein heifers (Putney et al., 1989). Furthermore, direct exposure of maturing ova to $41.0^{\circ} \mathrm{C}$ during in vitro maturation (IVM) resulted in similar reductions in embryonic development when in vitro fertilization (IVF) was performed at 22 to $24 \mathrm{~h}$ of in vitro maturation (hIVM; Edwards and Hansen, 1996; Lawrence et al., 2004; Roth and Hansen, 2004).

Oocyte maturation coincides with expression of estrus in the cow and is important to prepare the ovum for fertilization. Changes occurring in the nucleus are referred to as nuclear maturation [i.e., resumption of meiosis ensues, culminating in extrusion of the first polar body and arrest of the maternal chromatin at metaphase II (MII)]. Marked changes occurring in the ooplasm are referred to as cytoplasmic maturation and include redistribution of organelles (e.g., translocation of cortical granules to the oolemma), reduced abundance of maternal transcripts, and changes in protein synthetic profiles (reviewed by Sirard et al., 2006).

In vitro-matured ova undergo nuclear and cytoplasmic maturation similar to the in vivo counterparts. Progression to MII is often completed by 16 to $22 \mathrm{~h}$ after resumption of meiosis, whereas translocation of cortical granules is noted between 20 to $30 \mathrm{~h}$ (in vivo, Kruip et al., 1983; in vitro, Hyttel et al., 1986; Edwards et al., 2005). To obtain developmentally competent embryos, the time period for fertilizing mature ova is finite (in vivo: 8 to $10 \mathrm{~h}$, Hunter, 1985; in vitro: 4 to $8 \mathrm{~h}$, Ward et al., 2002). For example, Ward et al. (2002) demonstrated that blastocyst development was max- 
imized when IVF was performed at 24 hIVM; performing IVF earlier (e.g., 16 or 20 hIVM) or later (e.g., 28 or 32 hIVM) reduced blastocyst development. The presence of interconnected and surrounding cumulus with the ovum may create a similar microenvironment to explain in part why in vitro procedures are supportive of embryonic development and have resulted in comparable pregnancy and calving rates after transfer into Holstein heifers (Hasler, 2000).

Using the IVM and IVF procedures described herein, Edwards et al. (2005) demonstrated that direct effects of heat stress were not to inhibit, but to hasten oocyte maturation. Specifically, more heat-stressed ova progressed to metaphase I by $8 \mathrm{hIVM}$ and to MII by 18 hIVM, and completed cortical granule translocation to the oolemma by 24 hIVM compared with non-heatstressed controls. Thus, IVF, when performed at the same time as for non-heat-stressed controls (i.e., 24 hIVM), most likely results in fertilization of an "aged" ovum (i.e., a heat-stressed ovum that is arrested at MII longer than a non-heat-stressed ovum). In support of this result, Edwards et al. (2005) showed that performing IVF at $19 \mathrm{hIVM}$ minimized heat-induced reductions in blastocyst development. However, the choice of only one time period limited further inference regarding the extent to which earlier IVF may improve the development of heat-stressed ova.

In the present study, blastocyst development of embryos derived from control $\left(38.5^{\circ} \mathrm{C}\right)$ or heat-stressed $\left(41.0^{\circ} \mathrm{C}\right)$ ova was evaluated when IVF was performed at $16,18,20,24$, or $30 \mathrm{hIVM}$. The experimental design permitted 1) evaluation of the extent to which earlier fertilization may be beneficial to improve the development of heat-stressed ova, and 2) determination of the optimal time period during IVM to perform IVF and obtain maximal blastocyst development from heatstressed ova. Efforts to assign numeric scores to resulting embryos were important for evaluating the possible impact of IVM temperature or IVF time in influencing blastocyst stage and quality.

\section{MATERIALS AND METHODS}

\section{Materials}

Unless otherwise noted, all reagents and chemicals were purchased from Sigma Chemical Co. (St. Louis, MO). Modified Tyrode's albumin lactate pyruvate (HEPES-TALP, IVF-TALP, and Sperm-TALP) was prepared as previously described (Parrish et al., 1988). Potassium simplex optimized medium was prepared according to Biggers et al. (2000) but modified to contain $0.5 \%$ BSA, $10 \mathrm{~m} M$ glycine, $1 \mathrm{~m} M$ L-glutamine, $1 \times$ nonessential AA, $50 \mathrm{U} / \mathrm{mL}$ of penicillin, and $50 \mu \mathrm{g} / \mathrm{mL}$ of streptomycin (mKSOM). Medium-199, gentamicin, and penicillin-streptomycin were purchased from Invitrogen (Carlsbad, CA). Fetal bovine serum was obtained from BioWhittaker (Walkersville, MD). Folliclestimulating hormone (Folltropin-V) was obtained from Vetrepharm, Canada Inc. (London, Ontario, Canada). Frozen semen was donated by Harrogate Genetics Inc. (Harrogate, TN). Bovine ovaries were purchased from a commercial abattoir.

\section{In Vitro Production of Embryos}

In vitro maturation, IVF, and embryo culture were performed as previously described (Lawrence et al., 2004; Edwards et al., 2005). Cumulus-oocyte complexes (COC) collected from antral follicles (3 to $10 \mathrm{~mm}$ ) were cultured in groups of 35 to 50 in $500 \mu \mathrm{L}$ of oocyte maturation medium (medium-199 with Earle's salts, 10\% fetal bovine serum, $50 \mu \mathrm{g} / \mathrm{mL}$ of gentamicin, $5.0 \mu \mathrm{g} /$ $\mathrm{mL}$ of FSH, $0.2 \mathrm{~m} M$ sodium pyruvate, and $2 \mathrm{mM}$ Lglutamine) in Nunclon 4-well plates (Fisher Scientific, Pittsburgh, PA). Cumulus-oocyte complexes were fertilized with Percoll-prepared frozen-thawed bovine sperm $(500,000$ motile sperm $/ \mathrm{mL})$. Pooled semen from 2 bulls was used for each experimental replicate. Resulting putative zygotes (PZ) were denuded of cumulus and associated spermatozoa (18 to $19 \mathrm{~h}$ after IVF) by vortexing for 4 min in HEPES-TALP containing $0.3 \mathrm{mg} /$ $\mathrm{mL}$ of hyaluronidase, washed extensively, and then cultured in $\mathrm{mKSOM}$ at $38.5^{\circ} \mathrm{C}$ in $5.5 \% \mathrm{CO}_{2}, 7.0 \% \mathrm{O}_{2}$, and $87.5 \% \mathrm{~N}_{2}$.

\section{Development of Control and Heat-Stressed Ova When IVF Was Performed at 16, 18, 20, 24, or 30 hIVM}

Only COC having a dark and evenly granulated ooplasm with a compact cumulus (consisting of multiple layers) were cultured at 38.5 (control) or $41.0^{\circ} \mathrm{C}$ (heat stress for first $12 \mathrm{hIVM}$ ). Sperm was added to control and heat-stressed COC at 16, 18, 20, 24, or 30 hIVM, resulting in 10 different possible treatment combinations per experimental replicate. In one experimental replicate, however, IVF was performed at 32 rather than 30 hIVM. The number of PZ recovered and all PZ that had visibly lysed after denudement were recorded. The ability of PZ to cleave (assessed by recording the number of 1-, 2-, 4-, and 8- to 16-cell embryos at 52 to $72 \mathrm{~h}$ postinsemination) and develop to the blastocyst stage (180 to $192 \mathrm{~h}$ postinsemination) were evaluated. Additionally, blastocysts were assigned a numeric score for stage (early $=5$, normal $=6$, expanding $=7$, and hatched $=8$ ) and quality [excellent or good $=1$ (symmetrical embryo, uniform individual blastomeres, with at least $85 \%$ of cellular material as an intact viable embry- 
onic mass), fair $=2$ (moderate irregularities in shape of embryo, with at least $50 \%$ of cellular material as an intact viable mass), poor $=3$ (major irregularities in shape of embryonic mass or size, with at least $25 \%$ of cellular material as an intact viable mass), or degenerate $=4$ ] according to International Embryo Transfer Society guidelines (Stringfellow and Seidel, 1998). The experiment was replicated on 9 different occasions. In total, 300 to $430 \mathrm{COC}$ were cultured, yielding 7 to 9 experimental units (groups of COC) per treatment combination.

\section{Statistical Analyses}

Data were analyzed as a randomized incomplete block design, blocking on replicate, by using generalized linear mixed models (PROC GLIMMIX) in SAS (SAS Institute, 2005). GLIMMIX fits models with random and fixed effects for normally distributed (blastocyst stage and quality scores) or binomial response data (all other variables). Fixed effects in the model included the main effects of IVM temperature $\left(38.5\right.$ or $\left.41.0^{\circ} \mathrm{C}\right)$ and IVF time $(16,18,20,24$, or $30 \mathrm{hIVM})$ and the interaction of IVM temperature $\times$ IVF time. Data were expressed as least squares means \pm standard errors of the mean back-transformed with the inverse link option. Protected least significant differences were used to identify treatment differences.

An additional analysis was performed a posteriori to compare blastocyst development derived from control ova undergoing IVF at 20,24, 30, or $32 \mathrm{hIVM}$ and heatstressed ova undergoing IVF at 16, 18, 20, or 24 hIVM (i.e., time periods when development rose and declined from peak values). Data were blocked on replicate and analyzed with a binomial distribution using multisource nonlinear mixed model regression (PROC NLMIXED; SAS Institute, 2005). A quadratic regression model, $\mathrm{y}=\mathrm{A}+\mathrm{B} \times(\mathrm{x}+\mathrm{S})+\mathrm{C} \times(\mathrm{x}+\mathrm{S})^{2}$, was used to fit separate developmental response curves for control and heat-stressed COC ( $\mathrm{y}=$ blastocyst development, $\mathrm{A}=$ intercept, $\mathrm{B}=$ linear slope, $\mathrm{C}=$ quadratic slope, $\mathrm{x}=$ IVF time, and $\mathrm{S}=$ shift in IVF time). The parameter S was included only for heat-stressed data, thus requiring a nonlinear model. The best fitting model was chosen by comparing -2 log likelihoods of full to reduced parameter models. A coefficient of determination was derived from likelihoods to evaluate how well the model fit the data (Nagelkerke, 1991). Maximumlikelihood estimates were reported with $95 \%$ confidence intervals $(\mathbf{C I})$.

\section{RESULTS}

Culture of COC at $41.0^{\circ} \mathrm{C}$ did not alter the proportion of $\mathrm{PZ}$ recovered or those that had visibly lysed after denudement of cumulus cells and associated spermatozoa (Table 1). Additionally, maturation of COC at $41.0^{\circ} \mathrm{C}$ did not alter the ability to cleave, alter the ability to develop to the 8- to 16-cell stage after IVF, or influence the stage and quality of resulting blastocysts (Table 1).

In vitro fertilization time did not alter the proportion of PZ recovered or those that had visibly lysed after denudement of cumulus cells and associated spermatozoa (Table 1). Additionally, the ability of PZ to cleave did not differ according to IVF time (Table 1). However, when IVF was performed at 16,18 , or 30 hIVM, the proportion of 8- to 16-cell embryos was reduced compared with 24-hIVM controls $(P=0.0001$; Table 1$)$. Concurrent with this effect was an increase in the proportion of 4-cell embryos when IVF occurred at 16, 18, or 30 hIVM compared with 24 -hIVM controls $(P=0.014$; Table 1). These effects were without consequence on the stage and quality of resulting blastocysts (Table 1).

However, a significant IVM temperature $\times$ IVF time interaction was noted when evaluating the proportion of COC that developed to the blastocyst stage $(\mathrm{SEM}=$ 2.2; $P<0.0001$; Figure 1). Culture of COC at $41.0^{\circ} \mathrm{C}$ for the first $12 \mathrm{~h}$ of IVM reduced blastocyst development when IVF was performed at 24 hIVM compared with the respective control. A similar effect was observed when IVF was performed at 30 hIVM. However, when heat-stressed COC underwent IVF at 16, 18, or 20 hIVM, blastocyst development was greater than that of the respective controls. Earlier IVF was beneficial, because development of heat-stressed COC undergoing IVF at 18 or $20 \mathrm{hIVM}$ was greater than development of heat-stressed COC undergoing IVF at 24 hIVM. In fact, blastocyst development of heat-stressed COC undergoing IVF at 18 hIVM was comparable to non-heatstressed control COC undergoing IVF at 24 hIVM.

The multisource regression analysis showed that culture of $\mathrm{COC}$ at $41.0^{\circ} \mathrm{C}$ did not alter the linear or quadratic slopes of the blastocyst developmental response curve (full model minus reduced model -2 log likelihood $=0$ ). However, the effect of heat stress was to shift the developmental responsiveness of ova by $7.3 \mathrm{~h}(95 \%$ $\mathrm{CI}=5.5$ to $8.9 \mathrm{~h} ; P=0.0001$; Figure 2 ). In other words, obtaining optimal blastocyst development from heatstressed COC depended on performing IVF at 19.5 hIVM (95\% CI $=18.3$ to $20.6 \mathrm{hIVM}$ ) compared with $26.7 \mathrm{hIVM}$ (95\% CI = 25.5 to $27.8 \mathrm{hIVM}$ ) for non-heatstressed controls. The model explained $52 \%$ of the variation.

Heat stress decreased the intercept and peak of the developmental response curve, thereby reducing optimal blastocyst development by $9.5 \%$ (95\% CI $=4.7$ to $14.3 \% ; P=0.002$ ). Predicted optimal development was $31.8(95 \% \mathrm{CI}=26.5$ to $37.2 \%)$ vs. $22.3 \%(95 \% \mathrm{CI}=19.1$ to 
Table 1. Least squares means of developmental end points after maturing bovine ova at 2 different in vitro maturation (IVM) temperatures and performing in vitro fertilization (IVF) at 5 different times

\begin{tabular}{|c|c|c|c|c|c|c|c|}
\hline Effect & $\begin{array}{l}\text { Recovered } \\
(\%)\end{array}$ & $\begin{array}{l}\text { Lysed } \\
(\%)\end{array}$ & $\begin{array}{c}\text { Cleaved } \\
(\%)\end{array}$ & $\begin{array}{l}\text { 4-cell } \\
(\%)\end{array}$ & $\begin{array}{c}\text { 8- to } 16 \text {-cell } \\
(\%)\end{array}$ & $\begin{array}{l}\text { Blastocyst } \\
\text { stage }\end{array}$ & $\begin{array}{c}\text { Blastocyst } \\
\text { quality }\end{array}$ \\
\hline \multicolumn{8}{|c|}{ IVM temperature $\left({ }^{\circ} \mathrm{C}\right)$} \\
\hline 38.5 & 95.6 & 5.2 & 71.0 & 39.0 & 48.1 & 6.0 & 1.7 \\
\hline 41.0 & 95.0 & 4.7 & 70.2 & 38.2 & 50.2 & 6.0 & 1.7 \\
\hline SEM & 0.7 & 0.6 & 2.8 & 2.1 & 4.4 & 0.1 & 0.1 \\
\hline$P$-value & 0.498 & 0.439 & 0.637 & 0.705 & 0.327 & 0.556 & 0.579 \\
\hline \multicolumn{8}{|l|}{ IVF time $\left(\mathrm{hIVM}^{1}\right)$} \\
\hline 16 & 95.3 & 6.0 & 67.8 & $40.6^{\mathrm{a}}$ & $45.1^{\mathrm{c}}$ & 5.9 & 1.7 \\
\hline 18 & 94.5 & 4.4 & 73.4 & $41.8^{\mathrm{a}}$ & $48.0^{\mathrm{bc}}$ & 6.1 & 1.7 \\
\hline 20 & 95.9 & 4.2 & 69.7 & $36.4^{\mathrm{ab}}$ & $52.3^{\mathrm{ab}}$ & 6.0 & 1.7 \\
\hline 24 & 94.1 & 5.2 & 72.5 & $32.5^{\mathrm{b}}$ & $58.5^{\mathrm{a}}$ & 5.9 & 1.7 \\
\hline 30 & 96.4 & 5.2 & 69.7 & $42.1^{\mathrm{a}}$ & $41.9^{\mathrm{c}}$ & 6.1 & 1.7 \\
\hline SEM & 1.0 & 0.1 & 3.1 & 2.7 & 4.7 & 0.1 & 0.1 \\
\hline$P$-value & 0.394 & 0.555 & 0.187 & 0.014 & 0.0001 & 0.356 & 0.936 \\
\hline \multicolumn{8}{|c|}{ IVM temperature $\times$ IVF time } \\
\hline $38.5^{\circ} \mathrm{C} / 16 \mathrm{hIVM}$ & 95.3 & 7.1 & 63.8 & 40.4 & 42.5 & 5.9 & 1.8 \\
\hline $41.0^{\circ} \mathrm{C} / 16 \mathrm{hIVM}$ & 95.2 & 5.1 & 71.5 & 40.7 & 47.8 & 6.0 & 1.7 \\
\hline $38.5^{\circ} \mathrm{C} / 18 \mathrm{hIVM}$ & 93.3 & 4.6 & 73.0 & 42.0 & 45.8 & 6.1 & 1.7 \\
\hline $41.0^{\circ} \mathrm{C} / 18 \mathrm{hIVM}$ & 95.5 & 4.2 & 73.8 & 41.6 & 50.2 & 6.0 & 1.8 \\
\hline $38.5^{\circ} \mathrm{C} / 20 \mathrm{hIVM}$ & 94.8 & 4.2 & 69.8 & 37.6 & 47.5 & 6.1 & 1.7 \\
\hline $41.0^{\circ} \mathrm{C} / 20 \mathrm{hIVM}$ & 96.7 & 4.3 & 69.6 & 35.2 & 57.1 & 5.8 & 1.8 \\
\hline $38.5^{\circ} \mathrm{C} / 24 \mathrm{hIVM}$ & 94.9 & 7.3 & 75.1 & 33.5 & 57.9 & 5.9 & 1.7 \\
\hline $41.0^{\circ} \mathrm{C} / 24 \mathrm{hIVM}$ & 93.2 & 3.7 & 69.7 & 31.5 & 59.0 & 5.9 & 1.6 \\
\hline $38.5^{\circ} \mathrm{C} / 30 \mathrm{hIVM}$ & 97.9 & 4.1 & 72.8 & 41.7 & 46.8 & 6.1 & 1.6 \\
\hline $41.0^{\circ} \mathrm{C} / 30 \mathrm{hIVM}$ & 93.7 & 6.7 & 66.3 & 42.6 & 37.1 & 6.1 & 1.9 \\
\hline SEM & 1.3 & 1.2 & 3.6 & 3.6 & 5.3 & 0.1 & 0.1 \\
\hline$P$-value & 0.090 & 0.159 & 0.074 & 0.979 & 0.081 & 0.678 & 0.460 \\
\hline
\end{tabular}

${ }^{\mathrm{a}-\mathrm{c}}$ Means within a column with different superscripts differ $(P<0.05)$.

${ }^{1} \mathrm{hIVM}=\mathrm{h}$ of in vitro maturation.

25.5\%) for control and heat-stressed COC, respectively. Heat-induced reduction in the height of the developmental response curve reduced the window of time to perform IVF and obtain $\geq 20 \%$ blastocyst development

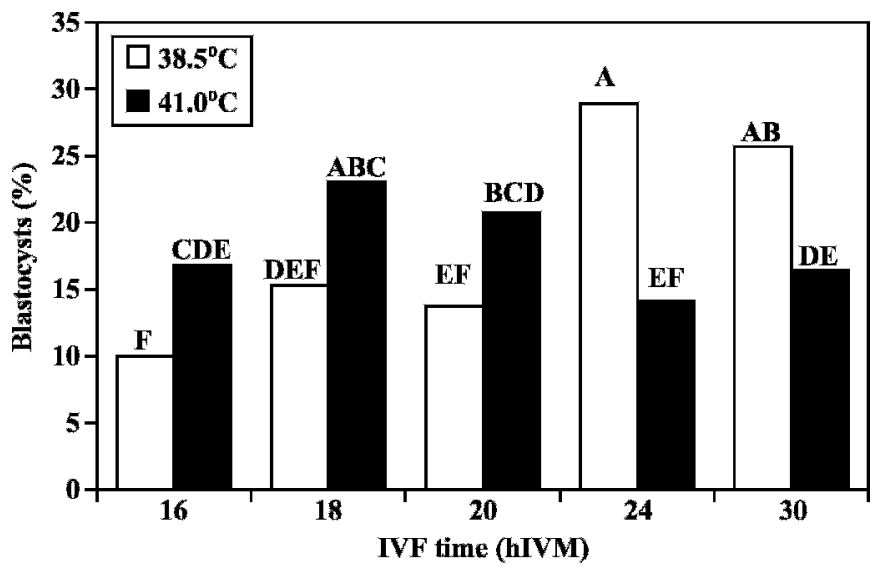

Figure 1. Cumulus-oocyte complexes (COC) were cultured at 38.5 or $41.0^{\circ} \mathrm{C}$ [heat stress for first $12 \mathrm{~h}$ of in vitro maturation (hIVM)]. Sperm was added to COC at 16, 18, 20, 24, or 30 hIVM. Blastocyst development was recorded at 180 to $192 \mathrm{~h}$ after in vitro fertilization (IVF). In vitro maturation temperature $\times$ IVF time interaction; $P<$ $0.0001 ; \mathrm{SEM}=2.2 .{ }^{\mathrm{A}-\mathrm{F}}$ Means with different uppercase letters differ. by $6.1 \mathrm{~h}(95 \% \mathrm{CI}=2.5$ to $9.7 \mathrm{~h} ; P=0.004)$. In other words, obtaining $\geq 20 \%$ blastocyst development from heat-stressed COC depended on performing IVF between 17.1 and $21.8 \mathrm{hIVM}$ ( $4.7 \mathrm{~h}$ duration). In contrast, obtaining $\geq 20 \%$ blastocyst development from control COC depended on performing IVF between 21.3 and $32.1 \mathrm{hIVM}$ (10.8 h duration).

Because regression can have more power than ANOVA when describing the relationship between a response variable and a continuous independent variable (Cottingham et al., 2005), blastocyst development of heat-stressed COC after IVF at 18 hIVM was compared with non-heat-stressed COC after IVF at 24 hIVM to clarify the GLIMMIX results in Figure 1. When this was done, the regression analysis showed a 7.4\% (95\% $\mathrm{CI}=2.4$ to $12.5 \% ; P=0.009)$ difference in the development of control (28.9\%) vs. heat-stressed (21.5\%) COC.

\section{DISCUSSION}

This study documented the extent to which effects of heat stress on the maturing ovum that compromise subsequent development depended on when IVF was performed. Unexpectedly, a higher proportion of heatstressed ova developed to the blastocyst stage compared 


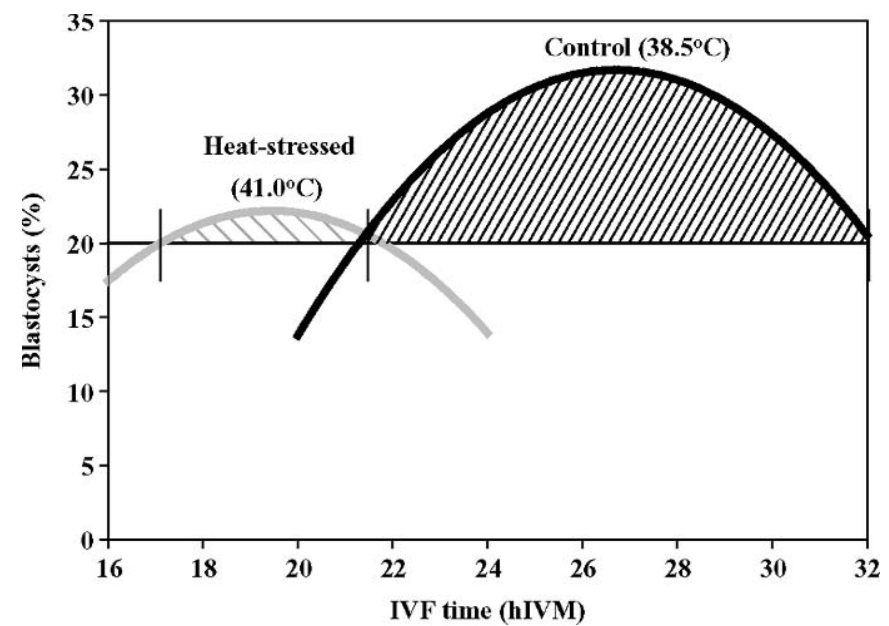

Figure 2. Developmental response curves for control $\left(38.5^{\circ} \mathrm{C}\right)$ and heat-stressed $\left(41.0^{\circ} \mathrm{C}\right)$ ova undergoing in vitro fertilization (IVF) at different hours of in vitro maturation (hIVM). Shaded portions represent the duration of time during in vitro maturation to perform IVF and obtain $\geq 20 \%$ blastocyst development. Regression equations were $-252.2+21.3 \mathrm{x}-0.4 \mathrm{x}^{2}$ and $-261.7+21.3(\mathrm{x}+7.3)-0.4(\mathrm{x}+7.3)^{2}$ for control and heat-stressed ova, respectively $\left(\mathrm{R}^{2}=0.52\right)$

with respective controls when IVF was performed at 16,18 , or 20 hIVM. This finding was in stark contrast to heat-induced reductions in the development of maturing ova when IVF was performed at approximately 24 hIVM (this study; Edwards and Hansen, 1996; Lawrence et al., 2004; Roth and Hansen, 2004; Edwards et al., 2005). Performing IVF earlier than usual was beneficial, because blastocyst development of heatstressed ova was greatly improved when IVF was performed at 18 or $20 \mathrm{hIVM}$ (23.1 and $20.7 \%$ ) vs. 24 hIVM (14.1\%). Regression analysis was important to identify the time period during IVM to perform IVF and obtain $\geq 20 \%$ blastocyst development from heat-stressed ova. In the context of this study, this time period was between 17.1 and 21.8 hIVM. Obtaining maximal blastocyst development from heat-stressed ova depended on performing IVF at $19.5 \mathrm{hIVM}$.

An effect of heat stress of shifting developmental responsiveness of ova by $7.3 \mathrm{~h}$ supports previous observations of Edwards et al. (2005) showing that heatstressed ova mature faster than controls. Taken together, these data provide compelling evidence for a cumulative effect of heat stress to hasten developmentally important processes in the maturing ovum such that fertilization of an "aged" ovum would be a major consequence if heat-stressed ova underwent IVF at the same time as non-heat-stressed controls. In support of this view, both aged (Ward et al., 2002; Agung et al., 2006) and heat-stressed (Edwards and Hansen, 1996; Lawrence et al., 2004; Roth and Hansen, 2004) ova are known to have reduced blastocyst development after fertilization. Ward et al. (2002) and Agung et al. (2006) reported a 35 to $50 \%$ reduction in blastocyst development after ova were aged 8 to $10 \mathrm{~h}$ before IVF. Moreover, it is not atypical for heat-stressed ova to experience a 35 to $50 \%$ reduction in blastocyst development when IVF is performed at approximately $24 \mathrm{hIVM} \mathrm{(Edwards}$ and Hansen, 1996; Lawrence et al., 2004; Roth and Hansen, 2004). Other similarities exist between aged vs. heat-stressed ova, including reduced abundance of maternal transcripts and synthesis of intracellular proteins (Edwards and Hansen, 1996; Xu et al., 1997; Payton and Edwards, 2005). In extreme cases, sperm penetration may be reduced (Tarin et al., 2000; Roth and Hansen, 2005) and ova may undergo apoptosis (Fissore et al., 2002; Roth and Hansen, 2004).

In this study, blastocyst development (28.9\%) fell within the expected range of 20 to $50 \%$ for ova matured at $38.5^{\circ} \mathrm{C}$ and undergoing IVF at approximately 24 hIVM (Moore and Thatcher, 2006). The reality of obtaining development from heat-stressed ova rarely exceeding 10 to $15 \%$ after IVF at 22 to 24 hIVM (this study; Edwards and Hansen, 1996; Lawrence et al., 2004; Roth and Hansen, 2004) attests to the significance of obtaining $\geq 20 \%$ blastocyst development from heatstressed ova, particularly because blastocysts derived from heat-stressed ova were equivalent in stage and quality to non-heat-stressed controls. Although we are cognizant of possible differences in the responsiveness of maturing ova to heat stress when derived from 3- to $10-\mathrm{mm}$ antral follicles vs. those undergoing the final stages of antral development, it is interesting to note that pregnancy rates of dairy cows in the most southern states during winter (15 to $30 \%$ ) and summer (5 to 15\%; reviewed by Jordan, 2003; de Vries and Risco, 2005) often parallel the efficiency of in vitro procedures when ova are matured at thermoneutral vs. heat-stressed conditions.

Despite progress in obtaining development from heat-stressed ova approaching control values $(\geq 20 \%$ blastocyst), the multisource regression analysis showed that earlier IVF was not entirely effective in eliminating all the negative effects of heat stress (i.e., development of heat-stressed ova undergoing IVF at $18 \mathrm{hIVM}$ was higher than the respective controls but still lower than non-heat-stressed controls undergoing IVF at 24 hIVM). Although mechanism(s) or factor(s) accounting for reduced development in aged and heat-stressed ova remain elusive, oxidative stress may be a contributing factor. Reductions in the development of mature murine ova aged for 6 to $10 \mathrm{~h}$ after ovulation have been associated with increases in lipid peroxidation (an indicator of oxidative stress) and perturbations in developmentally important calcium oscillations (Takahashi et al., 2003). Likewise, decreased blastocyst development in heat- 
stressed bovine zygotes and early embryos has been associated with heat-induced increases in oxidative stress (Sakatani et al., 2004). The presence with the bovine ovum of interconnected, surrounding cumulus continues to hamper efforts to clarify the extent to which heat stress may increase oxidative stress during the initial phases of maturation. However, beneficial effects of an antioxidant to minimize heat-induced reductions in blastocyst development after heat-stressed ova were matured in the presence of $5 \mu M$ retinol (Lawrence et al., 2004) support this notion.

Certainly, some of the negative effects of heat stress in reducing ovum development may be mediated through cumulus. These cells project through the zona pellucida and through the oolemma as a means of establishing an intercellular bidirectional form of communication (reviewed by Eppig, 1994). Prolonged exposure to heat stress reduces hyaluronic acid production and cumulus cell expansion (Lenz et al., 1983). However, consequences occurring after shorter durations of heat stress remain unclear, because cumulus expansion appears comparable to controls.

Nonetheless, oocyte maturation in the dairy cow occurs while the ovum resides in the Graafian follicle and is completed 20 to $24 \mathrm{~h}$ after the LH surge (Kruip et al., 1983). Ovulation occurring at 26 to $30 \mathrm{~h}$ after the LH surge (Kruip et al., 1983; Kaim et al., 2003) effectively ensures fertilization of a matured ovum. Thus, if the effect of elevated maternal temperatures is to hasten oocyte maturation in vivo, then development of therapeutic strategies to ensure ovulation of the ovum during its fertile life span, while protecting it from oxidative stress, will be important. However, because efforts to alter the timing of ovulation may pose different challenges with possible negative effects on fertility, development of therapeutic strategies to prevent hastened maturation would be most preferable. Antioxidant therapies may be useful, because slight improvements in the pregnancy rates of heat-stressed dairy cows have been observed (Aréchiga et al., 1998).

\section{CONCLUSIONS}

Continued efforts to identify ovum components perturbed after direct application of heat stress and the consequences thereof are important, because the oocyte contributes greater than $99 \%$ of cytoplasm and half the genetic material to the resulting embryo after fertilization. Experimental effort to gain a better understanding of the basic mechanisms whereby heat stress reduces ovum development is an important first step in the continuum of efforts toward the development of management strategies aimed at improving dairy cow fertility related to poor ovum quality. To this end, the data summarized in this manuscript provide compelling evidence for a cumulative effect of heat stress to hasten developmentally important processes in the maturing ovum. If heat-stressed ova undergo IVF at the same time as non-heat-stressed controls, then a major consequence would be fertilization of an "aged" ovum. Although earlier IVF improved the development of heatstressed ova, the inability to fully restore development of heat-stressed ova to values expected for non-heatstressed controls undergoing IVF at the most optimal time period (i.e., $26.7 \mathrm{hIVM}$ in this study) highlights the importance of further study.

\section{ACKNOWLEDGMENTS}

This research was supported in part by National Research Initiative Competitive Grant No. 2004-3520314772 from the USDA Cooperative State Research, Education, and Extension Service, USDA Hatch Funds, and the State of Tennessee through the Tennessee Agricultural Experiment Station and the Department of Animal Science (participation in the S-1023 Regional Heat Stress Project). Appreciation is extended to T. J. Wilson, Rebecca Payton, Amber Bogart, Ariel Best, F. N. Scenna, and L. A. Rispoli for assistance in conducting the experiment and to Harrogate Genetics Inc. (Harrogate, TN) for generously donating frozen semen.

\section{REFERENCES}

Agung, B., T. Otoi, P. Wongsrikeao, M. Taniguchi, R. Shimizu, H. Watari, and T. Nagai. 2006. Effect of maturation culture period of oocytes on the sex ratio of in vitro fertilized bovine embryos. J. Reprod. Dev. 52:123-127.

Aréchiga, C. F., C. R. Staples, L. R. McDowell, and P. J. Hansen. 1998. Effects of timed insemination and supplemental $\beta$-carotene on reproduction and milk yield of dairy cows under heat stress. J. Dairy Sci. 81:390-402.

Biggers, J. D., L. K. McGinnis, and M. Raffin. 2000. Amino acids and preimplantation development of the mouse in protein-free potassium simplex optimized medium. Biol. Reprod. 63:281-293.

Cottingham, K. L., J. T. Lennon, and B. L. Brown. 2005. Knowing when to draw the line: Designing more informative ecological experiments. Front. Ecol. Environ. 3:145-152.

de Vries, A., and C. A. Risco. 2005. Trends and seasonality of reproductive performance in Florida and Georgia dairy herds from 1976 to 2002. J. Dairy Sci. 88:3155-3165.

Edwards, J. L., and P. J. Hansen. 1996. Elevated temperature increases heat shock protein 70 synthesis in bovine two-cell embryos and compromises function of maturing oocytes. Biol. Reprod. $55: 340-346$

Edwards, J. L., A. M. Saxton, J. L. Lawrence, R. R. Payton, and J. R. Dunlap. 2005. Exposure to a physiologically relevant elevated temperature hastens in vitro maturation in bovine oocytes. J. Dairy Sci. 88:4326-4333.

Eppig, J. J. 1994. Oocyte-somatic cell communication in the ovarian follicles of mammals. Sem. Dev. Biol. 5:51-59.

Fissore, R. A., M. Kurokawa, J. Knott, M. Zhang, and J. Smyth. 2002. Mechanisms underlying oocyte activation and postovulatory ageing. Reproduction 124:745-754.

Hasler, J. F. 2000. In-vitro production of cattle embryos: Problems with pregnancies and parturition. Hum. Reprod. 15(Suppl. 5):47-58. 
Hunter, R. H. F. 1985. Fertility in cattle: Basic reasons why late insemination must be avoided. Anim. Breed. Abstr. 53:83-87.

Hyttel, P., K. P. Xu, S. Smith, and T. Greve. 1986. Ultrastructure of in-vitro oocyte maturation in cattle. J. Reprod. Fertil. 78:615-625.

Jordan, E. R. 2003. Effects of heat stress on reproduction. J. Dairy Sci. 86 (E. Suppl.):E104-E114.

Kaim, M., A. Bloch, D. Wolfenson, R. Braw-Tal, M. Rosenberg, H. Voet, and Y. Folman. 2003. Effects of GnRH administered to cows at the onset of estrus on timing of ovulation, endocrine responses, and conception. J. Dairy Sci. 86:2012-2021.

Kruip, T. A. M., D. G. Cran, T. H. van Beneden, and S. J. Dieleman. 1983. Structural changes in bovine oocytes during final maturation in vivo. Gamete Res. 8:29-47.

Lawrence, J. L., R. R. Payton, J. D. Godkin, A. M. Saxton, F. N. Schrick, and J. L. Edwards. 2004. Retinol improves development of bovine oocytes compromised by heat stress during maturation. J. Dairy Sci. 87:2449-2454.

Lenz, R. W., G. D. Ball, M. L. Leibfried, R. L. Ax, and N. L. First. 1983. In vitro maturation and fertilization of bovine oocytes are temperature-dependent processes. Biol. Reprod. 29:173-179.

Moore, K., and W. W. Thatcher. 2006. Major advances associated with reproduction in dairy cattle. J. Dairy Sci. 89:1254-1266.

Nagelkerke, N. J. D. 1991. A note on a general definition of the coefficient of determination. Biometrika 78:691-692.

Parrish, J. J., J. Susko-Parrish, M. A. Winer, and N. L. First. 1988. Capacitation of bovine sperm by heparin. Biol. Reprod. 38:1171-1180.

Payton, R. R., and J. L. Edwards. 2005. Effects of heat stress on RNA pools within maturing oocytes. Biol. Reprod. (Spec. Issue):134. (Abstr.)

Putney, D. J., S. Mullins, W. W. Thatcher, M. Drost, and T. S. Gross. 1989. Embryonic development in superovulated dairy cattle ex- posed to elevated ambient temperatures between the onset of estrus and insemination. Anim. Reprod. Sci. 19:37-51.

Roth, Z., and P. J. Hansen. 2004. Involvement of apoptosis in disruption of developmental competence of bovine oocytes by heat shock during maturation. Biol. Reprod. 71:1898-1906.

Roth, Z., and P. J. Hansen. 2005. Disruption of nuclear maturation and rearrangement of cytoskeletal elements in bovine oocytes exposed to heat shock during maturation. Reproduction 129:235-244.

Sakatani, M., S. Kobayashi, and M. Takahashi. 2004. Effects of heat shock on in vitro development and intracellular oxidative state of bovine preimplantation embryos. Mol. Reprod. Dev. 67:77-82.

SAS Institute. 2005. SAS User's Guide: Statistics. Version 9.1 Edition. SAS Inst. Inc., Cary, NC.

Sirard, M. A., F. Richard, P. Blondin, and C. Robert. 2006. Contribution of the oocyte to embryo quality. Theriogenology 65:126-136.

Stringfellow, D. A., and S. M. Seidel. 1998. Manual of the International Embryo Transfer Society. 3rd ed. Int. Embryo Transfer Soc., Savoy, IL.

Takahashi, T., E. Takahashi, H. Igarashi, N. Tezuka, and H. Kurachi. 2003. Impact of oxidative stress in aged mouse oocytes on calcium oscillations at fertilization. Mol. Reprod. Dev. 66:143-152.

Tarin, J. J., S. Perez-Albala, and A. Cano. 2000. Consequences on offspring of abnormal function in ageing gametes. Hum. Reprod. Update 6:532-549.

Ward, F., B. Enright, D. Rizos, M. Boland, and P. Lonergan. 2002. Optimization of in vitro bovine embryo production: Effect of duration of maturation, length of gamete co-incubation, sperm concentration and sire. Theriogenology 57:2105-2117.

Xu, Z., A. Abbott, G. S. Kopf, R. M. Schultz, and T. Ducibella. 1997. Spontaneous activation of ovulated mouse eggs: Time-dependent effects on M-phase exit, cortical granule exocytosis, maternal messenger ribonucleic acid recruitment, and inositol 1,4,5-trisphosphate sensitivity. Biol. Reprod. 57:743-750. 